\title{
Situational diagnosis of older adults with diabetes mellitus in a city in the state of Ceará, Brazil
}

Marcionília de Araújo Lima Netal ${ }^{\mathbb{D}}$ Maristela Inês Osawa Vasconcelos ${ }^{2}$ iD

\section{Abstract}

Objective: To describe the situational diagnosis of older adults with diabetes mellitus (DM) registered at a Basic Family Health Unit, using sociodemographic profile, health conditions and lifestyle. Method: A descriptive, cross-sectional study was carried out with 70 older adults in the city of Jijoca de Jericoacoara, Ceará, Brazil. Data were gathered from questionnaires on sociodemographic conditions, health and individual lifestyle profile, and were submitted to descriptive statistics techniques, and the results presented in tables. Results: The predominance of women was three times greater than men $(52=74 \%)$; the mean age was 71.19 years $( \pm 7.12)$; the number of married people was higher than the other categories $(44=62.8 \%)$; the vast majority of the sample received a pension equivalent to the minimum wage as a rural worker $(64=91 \%)$; and just over half declared themselves to be literate $(36=51.4 \%$ ). In terms of health conditions, the majority $(56=80 \%)$ had had DM for more than 10 years, although they considered their health status to be satisfactory $(40=57.14 \%)$. Among the main complications were hypertension $(n=53 ; 75.71 \%)$, muscle and joint pain $(\mathrm{n}=43 ; 61.43 \%)$ and hearing loss $(48=68.57 \%)$. Conclusion: The present study provided indicators for the planning and execution of educational actions, based on interprofessional collaboration aimed at the promotion of health.

\footnotetext{
Universidade Estadual Vale do Acaraú (UVA), Centro de Ciências da Saúde (CCS), Mestrado Profissional em Saúde da Família. Sobral, CE, Brasil.

2 Universidade Estadual Vale do Acaraú (UVA), Centro de Ciências da Saúde (CCS), Departamento de Enfermagem, Mestrado Profissional em Saúde da Família. Sobral, CE, Brasil.
}

Keywords: Health of the Elderly. Diabetes Mellitus. Chronic Disease. Primary Health Care. Family Health Strategy.

The authors declare there are no conflicts of interest in relation to the present study.

No funding was received in relation to the present study. 


\section{INTRODUCTION}

Diabetes mellitus (DM) is a chronic disease that represents a serious public health problem due to its high global prevalence, which is higher still among older adults, the morbidity it causes, and as it is one of the main cardiovascular and cerebrovascular risk factors. Its prevalence is also related to a sedentary lifestyle and the stress of urban life ${ }^{1}$.

The population of people with diabetes in Brazil is estimated at 13 million and the country occupies 4th position in the global ranking. Between 2006 and 2017, according to data from the Surveillance of Risk and Protection Factors for Chronic Diseases by Telephone Survey (or VIGITEL), the percentage of diabetes cases in the country rose from 5.5\% to $8.9 \%$. This survey also revealed an increase in cases of 54\% among men and 28\% among women, highlighting the increase in those aged over 65 and with only eight years of schooling (24\% and $14.8 \%$, respectively) $)^{2}$.

Considering the magnitude of the disease and its negative effects on the health of individuals, systematic monitoring becomes an important intervention strategy and method of controlling possible complications. When the disease reaches older adults, who have complex health demands, services must be able to respond adequately to the needs not only of disease prevention and control, but also of promoting active and healthy aging ${ }^{3}$.

In this context, the Family Health Strategy (FHS) aims to encourage the reorientation of health practices and actions, structured around the work of multiprofessional teams. By establishing the family as the center of care, it encourages bonds and contributes to continuous actions to promote health and education, aimed at the autonomy and well-being of individuals ${ }^{4}$.

In addition, the health care model proposed by the FHS presents a new perspective of care and a continuous stimulus to an advanced practice, aimed at the community as a whole. However, in order to carry out health practices consistent with the needs of the territory, it is necessary to strengthen the autonomy of the actors involved in the care process, breaking with traditional models of health care, valuing human singularities and knowledge of the reality and risks to which the population is exposed ${ }^{5}$.

This study is justified by the need to understand the reality of older adults diagnosed with diabetes and how their sociodemographic, health and lifestyle conditions can influence adherence to treatment and improve quality of life. It is also a relevant study for health professionals who are involved in the care of older adults, as it can guide them towards providing effective and comprehensive care aimed at meeting the biological and psychosocial needs of such users.

Thus, the objective of the present study was to describe the situational diagnosis of older adults with DM registered in a Basic Family Health Unit based on sociodemographic profile, health conditions and lifestyle.

\section{METHOD}

A descriptive, cross-sectional study, with a quantitative approach, was carried out in the municipality of Jijoca de Jericoacoara, Ceará, Brazil, with data collection taking place from April to July 2019.

This study is an excerpt from a study entitled Interprofessional Collaboration in the Promotion of Healthy Lifestyles for the Older Population with Diabetes Mellitus.

Jijoca, until 1989, was a district of the city of Cruz. Pursuant to Law No. 11,796 of 1990, it became an autonomous municipality, with Jericoacoara beach becoming part of its territory, and changed its name to Jijoca de Jericoacoara. It is $287 \mathrm{~km}$ from the capital Fortaleza and belongs to the northwestern mesoregion of Ceará ${ }^{6}$ and the 12th Acaraú region ${ }^{7}$, integrating Jericoacoara National Park.

According to data from the Brazilian Institute of Geography and Statistics (IBGE), the municipality had an estimated population of 19,816 people in 2019; a territorial area of $204,793 \mathrm{~km}^{2}$; a HDI of 0.652 (average) and a GDP per capita of $\mathrm{R} \$ 11,443.58$. Tourism is its main economic source, through Jericoacoara beach ${ }^{8}$. 
The municipality has six Basic Health Units where seven FHS teams work, supported by an Extended Family Health Center (EFHC) team.

For the selection of participants, a survey of the number of older adults, aged from 60 years old, with a medical diagnosis of DM was carried out by community health agents in their respective microareas, and the area with the largest number of patients with this profile was chosen. The team selected recruited more older adults, giving a total of 107 users. It was decided to exclude bedridden users and those restricted to home from the study, since, from this diagnostic stage, a collective educational intervention would be carried out, and 85 older people were ultimately identified.

For the sample calculation, a population of 85 older adults was used, with a 95\% confidence interval and a margin of error of $5 \%$, which resulted in a sample of 70 older adults. Everyone who agreed to participate in the research signed an Informed Consent Form (ICF), ensuring the right to privacy, secrecy, access to data or any other information, as well as the freedom to withdraw from the study, if they so wished.

The data collection instruments were: a Sociodemographic Questionnaire, which addressed issues related to sex, age, profession, education, income and whether the participant lived with people over 65; a Questionnaire on Health Conditions that considered Body Mass Index (BMI), self-reported health status, the presence of comorbidities (cardiovascular disease, respiratory disease, hypertension, depression, among others already listed in the questionnaire), the self-reporting of some symptoms also already contained in a list in the questionnaire (urinary incontinence, vision loss, feeling of sadness, loss of hearing, difficulty walking, among others) and the occurrence of falls and fainting in the six months before the interview.

The BMI considers the following cut-off points and classifications for older adults ( $\geq 60$ years): Low weight $\leq 22$; Adequate or Normal Weight $>22$ and $<27$; Overweight $\geq 27$, according to the Food and Nutrition Surveillance System (or SISVAN)?.

Another instrument was the Individual Lifestyle Profile (or ILP) developed by Nahas et al. ${ }^{10}$ and validated by Both et al. ${ }^{11}$, which evaluated the components of nutrition, physical activity, preventive behavior, relational behavior and stress control. The first two instruments were adapted from the study by Pimenta et al. ${ }^{12}$ and all were applied at home.

The Lifestyle Profile scale comprises a total of 15 questions, three for each of the lifestyle components. Each question has a Likert scale answer ranging from 0 to 3 . The values 0 and 1 are linked to a negative lifestyle profile, which correspond respectively to: is absolutely not part of my lifestyle and sometimes corresponds to my behavior. The responses associated with a positive profile are values 2 and 3, which describe, respectively: almost always true for my behavior and always true in my daily life ${ }^{10}$. Each component can score a maximum of 9 points and both the average and the median can vary from 0 to 3 .

The Shapiro-Wilk test was performed to assess the distribution of data at a $95 \%$ confidence interval $(p$-value $<0.05)$, followed by descriptive analysis of the data.

For the descriptive analysis of the components of the Lifestyle Profile Scale, the median (Ma) was used, as the variables did not comply with the assumptions of normality according to the Shapiro-Wilk Test. The median of each individual was calculated for each component of the scale, followed by the median of the total sample, the interquartile range (IIQ), minimum value (Min) and maximum value (Max), calculated by component and sex. Medians with values $\geq 2$ were considered positive behavior.

This research was submitted to the Ethics Committee of the Universidade Estadual Vale do Acaraú, following Resolution 466/12, dated December 12, 2012 for research involving human beings, and was approved under opinion No. 3,241,908.

\section{RESULTS}

Of the total of 70 older adults approached, most were women $(74 \%)$, while the average age of the participants was 71.19 years $( \pm 7.12)$, with a maximum age of 89 years and a minimum age of 60 years. The women were older than the men, as can be seen in Table 1. 
With regard to marital status, most women (51.9\%) and men (94.5\%) were married. The majority of both sexes were farm workers $(33(63.4 \%)$ of the women and 17 (94.5\%) of the men). Pensions were the most cited source of income among the participants, with 47 (90.4\%) of the women and 17 $(94.5 \%)$ of the men receiving this social security benefit. Regarding education, $30(57.7 \%)$ of the women reported knowing how to read and write and $12(66.7 \%)$ of the men reported not knowing how to read and write. Most women, 28 (53.8\%) stated that they had only 3 to 4 years of schooling. Among men, $8(44.4 \%)$ reported having no education and 8 (44.4\%) reported having 3 to 4 years of schooling. Regarding family life, the majority of women and men, $27(52 \%)$ and $14(78 \%)$ respectively, stated that they lived/resided with people over 65 years of age (Table 1).

Table 1. Sociodemographic characterization of the older participants. Jijoca de Jericoacoara, Ceara, 2019.

\begin{tabular}{|c|c|c|}
\hline Variables & $\begin{array}{l}\text { Women } \\
52(74 \%)\end{array}$ & $\begin{array}{l}\text { Men } \\
18(26 \%)\end{array}$ \\
\hline Average Age $( \pm)$ & $70.61( \pm 7.11)$ & $72.83( \pm 7.19)$ \\
\hline \multicolumn{3}{|l|}{ Age group (years) } \\
\hline $60-64$ & $11(21.1 \%)$ & $2(11.1 \%)$ \\
\hline $65-69$ & $15(28.8 \%)$ & $4(22.2 \%)$ \\
\hline $70-74$ & $11(21.1 \%)$ & $6(33.3 \%)$ \\
\hline $75-79$ & $9(17.3 \%)$ & $2(11.1 \%)$ \\
\hline 80 or + & $6(11.5 \%)$ & $4(22.2 \%)$ \\
\hline \multicolumn{3}{|l|}{ Marital status } \\
\hline Married & $27(51.9 \%)$ & $17(94.5 \%)$ \\
\hline Widowed & $20(38.4 \%)$ & 0 \\
\hline Divorced & $2(3.8 \%)$ & 0 \\
\hline Separated & $3(5.7 \%)$ & $1(5.5 \%)$ \\
\hline \multicolumn{3}{|l|}{ Profession } \\
\hline Farm worker & $33(63.4 \%)$ & $17(94.5 \%)$ \\
\hline Home worker & $5(9.6 \%)$ & 0 \\
\hline Seamstress & $5(9.6 \%)$ & 0 \\
\hline Other & $9(17.3 \%)$ & $1(5.5 \%)$ \\
\hline \multicolumn{3}{|l|}{ Income Source } \\
\hline Pension & $47(90.4 \%)$ & $17(94.5 \%)$ \\
\hline Private pension & $1(1.9 \%)$ & 0 \\
\hline Social payments & $3(5.8 \%)$ & 0 \\
\hline Work & $1(1.9 \%)$ & $1(5.5 \%)$ \\
\hline \multicolumn{3}{|l|}{ Literacy (Can read/write) } \\
\hline Yes & $30(57.7 \%)$ & $6(33.3 \%)$ \\
\hline No & $22(42.3 \%)$ & $12(66.7 \%)$ \\
\hline \multicolumn{3}{|l|}{ Education } \\
\hline None & $17(32.7 \%)$ & $8(44.4 \%)$ \\
\hline From 3 to 4 years of schooling & $28(53.8 \%)$ & $8(44.4 \%)$ \\
\hline 9 years of schooling & $6(11.6 \%)$ & $2(11.1 \%)$ \\
\hline Higher Education & $1(1.9 \%)$ & 0 \\
\hline \multicolumn{3}{|c|}{ Cohabitants $>65$ years old (lives/resides $>65$ years old (lives/resides with people older than 65 years old) } \\
\hline Yes & $27(52 \%)$ & $14(78 \%)$ \\
\hline No & $25(48 \%)$ & $4(22 \%)$ \\
\hline
\end{tabular}


Table 2 shows the health conditions of the older adults, broken down by sex. It was found that 40 $(57.14 \%)$ considered their health status to be satisfactory (good/very good), while 38 (54.29\%) were overweight. The mean BMI was $27.48( \pm 3.45)$ with a maximum value of 35.58 and a minimum value of 17.30. Thus, in the present study, BMI revealed a prevalence of overweight older adults with DM (54.29\%).

It was also observed that the most prevalent comorbidities were hypertension and arthritis; the most cited symptoms and manifestations were persistent sadness, muscle and joint pain and hearing loss. Falls and blackouts were not frequent. Of the 17 $(24.29 \%)$ who had a fall episode, 7 (41.18\%) needed the help of others to get up.

Table 3 shows the medians broken down by sex and their classification for each component of the ILP scale. It is noteworthy that physical activity had a negative profile classification for both men and women. The nutrition component, however, was classified as positive for both sexes, although men had a lower score than women. The other components evaluated presented maximum scores and were classified as having a positive profile.

Table 2. Relationship of the distribution of the health condition variables: health status; BMI; diseases combined with DM; symptoms and manifestations; falls and fainting episodes and reactions after the fall. Jijoca de Jericoacoara, Ceara, 2019.

\begin{tabular}{|c|c|c|}
\hline Variables & $\begin{array}{l}\text { Men } \\
\mathrm{n}(\%)\end{array}$ & $\begin{array}{l}\text { Women } \\
\mathrm{n}(\%)\end{array}$ \\
\hline Satisfactory health status (good/very good) & $13(72.22 \%)$ & $27(51.92 \%)$ \\
\hline Overweight & $10(55.56 \%)$ & $28(53.85 \%)$ \\
\hline Stroke & $6(33.33 \%)$ & $3(5.77 \%)$ \\
\hline Cardiovascular disease & $4(22.22)$ & $4(7.69 \%)$ \\
\hline Parkinson & $1(5.56 \%)$ & 0 \\
\hline Arthritis & 0 & $24(46.15 \%)$ \\
\hline Oncological Disease & 0 & $1(1.92 \%)$ \\
\hline Respiratory disease & $1(5.56 \%)$ & $5(9.62 \%)$ \\
\hline Alzheimer's disease & $1(5.56 \%)$ & $1(1.92 \%)$ \\
\hline Depression & $1(5.56 \%)$ & $9(17.31 \%)$ \\
\hline Systemic Arterial Hypertension & $8(44.44 \%)$ & $45(86.54 \%)$ \\
\hline Urinary incontinence & $6(33.33 \%)$ & $20(38.46 \%)$ \\
\hline Feeling of sadness & $3(16.67 \%)$ & $28(53.85 \%)$ \\
\hline Memory Loss & $4(22.22 \%)$ & $20(38.46 \%)$ \\
\hline Musculoskeletal and Osteoarticular Pain & $5(27.78 \%)$ & $38(73.08 \%)$ \\
\hline Difficulty walking & $4(22.22 \%)$ & $20(38.46 \%)$ \\
\hline Constant imbalances & $7(38.89 \%)$ & $20(38.46 \%)$ \\
\hline Reduced vision & $4(22.22 \%)$ & $11(21.15 \%)$ \\
\hline Hearing loss & $10(55.56 \%)$ & $38(73.08 \%)$ \\
\hline Falls/Blackouts (last 6 months) & $4(22.22 \%)$ & $13(25 \%)$ \\
\hline Needed help getting up after a fall & $1(25 \%)$ & $6(46.15 \%)$ \\
\hline
\end{tabular}


Table 3. Measures of central tendency of Lifestyle Profile scale scores and the classification of each component broken down by sex. Jijoca de Jericoacoara, Ceara, 2019.

\begin{tabular}{lllllll}
\hline \multirow{2}{*}{$\begin{array}{l}\text { Lifestyle Profile } \\
\text { Scale Component }\end{array}$} & Median & $\begin{array}{l}\text { Range } \\
\text { (Min-Max) }\end{array}$ & Classification & Median & $\begin{array}{l}\text { Range } \\
\text { (Min-Max) }\end{array}$ & Classification \\
\hline Nutrition & 2 & $0-3$ & Positive Profile & 3 & $0-3$ & Positive Profile \\
\hline Physical activity & 0,5 & $0-3$ & Negative Profile & 1 & $0-3$ & Negative Profile \\
\hline Preventive behavior & 3 & $2-3$ & Positive Profile & 3 & $0-3$ & Positive Profile \\
\hline Relational behavior & 3 & $1-3$ & Positive Profile & 3 & $0-3$ & Positive Profile \\
\hline Stress Management & 3 & $1-3$ & Positive Profile & 3 & $0-3$ & Positive Profile \\
\hline Lifestyle Profile Scale & 3 & $1-3$ & Positive Profile & 3 & $1-3$ & Positive Profile \\
\hline
\end{tabular}

\section{DISCUSSION}

The predominance of women in the population studied can be explained by the feminization of aging phenomenon, and also reflects the tendency of women to have a greater perception of diseases and self-care, seeking medical care more frequently in order to increase the probability of the diagnosis of disease ${ }^{13}$.

The findings related to gender corroborate those of the National Health Survey (or PNS) carried out in 2013, in which women (7.0\%) had a higher proportion of reports of diabetes diagnosis than men $(5.4 \%)^{14}$.

The average age of the sample was close to 72 years, which is in line with the epidemiological transition that Brazil is currently experiencing, characterized by an aging population and the prevalence of chronic diseases, such as diabetes itself. It is also important to note that the great majority of diabetes cases manifest themselves after the age of $40^{15}$.

As for age groups, most of the sample was aged between 60 and 74 years old, while women were younger, aged between 65 and 69 years old (27.14\%). There was a prevalence of women aged between 65 and 69 years old $(n=15 ; 28.8 \%$ ) while most men were aged between 70 and 74 years old $(n=6 ; 33.3 \%)$ The diagnosis of the disease becomes more common among older individuals ${ }^{16}$.

With regard to schooling, the findings of this study agreed with PNS data, as most participants reported having only a basic level of education, referring to the first years of schooling. The 2013 PNS found that the educational level that showed the highest prevalence of diabetes diagnosis was uneducated and those with an incomplete elementary school, with $9.6 \%{ }^{14}$.

A pension was the source of income most cited by participants (91\%). Such benefit comes from a working life spent in rural areas, especially in agriculture, as $71 \%$ of the older adults reported that they worked as farm workers.

In economic terms, a pension is of great significance, as it guarantees older adults their livelihood and the provision of their needs, in addition to increasing their household income, as before they basically depended on income from agricultural work, which it is not always stable or guaranteed ${ }^{15,16}$. In the study by Wanderley et al. ${ }^{17}$, the minimum wage, derived from a pension, was also the most reported family income among older adults with diabetes.

As for the findings regarding health status, $57.14 \%$ of the participants considered their health to be satisfactory (good/very good). This data is similar to that found in the study by Ferraz et al. ${ }^{18}$, carried out with older adults diagnosed with diabetes and hypertension in a city in the state of Bahia, in which $50.6 \%$ of the participants also considered their health status to be good.

It is believed that the fact that older adults with diabetes declare their health status to be good is related to the control of pathologies and access to 
medication and monitoring at the health unit, which is a positive point, demonstrating the possibility of control of the condition, and the fact that these older adults learn to live with diseases and develop coping strategies ${ }^{19}$.

Another variable assessed within the health conditions was BMI. BMI is a measure of body composition, which determines whether body mass (weight) is within the recommended range for health. It is useful for the nutritional diagnosis of older adults, in addition to being a simple method which can effectively predict future diseases, mortality and functional disability, and can be used as an initial screening technique, both for the diagnosis and the monitoring of diseases?.

The present study found that the majority of the older adults (54.29\%) were overweight, with emphasis on men $(55.56 \%)$. It should be highlighted that the male participants of this study also had scores $\leq 2$ in the evaluation of the nutrition and physical activity components, fundamental aspects for the reduction/ control of weight, highlighting the existence of risk behaviors in daily routines.

The Brazilian Diabetes Society reports that a 5 to $10 \%$ decrease in body weight can reduce blood glucose levels, postpone the progression of the disease, reduce insulin needs and, even in initial cases, allow the withdrawal of pharmacological treatment ${ }^{2}$.

The high prevalence of overweight older adults is associated with the aging process, which is accompanied by several changes, among which are changes in the body composition of individuals, which occur as a natural factor of senescence and/ or due to the occurrence of metabolic disorders ${ }^{20}$.

With regard to diseases associated with diabetes, there was a prevalence of hypertension, with an especially high percentage among women (86.54\%).

This finding also warns of a concern of the Ministry of Health in recent years, as the combination of Systemic Arterial Hypertension (SAH) and DM is even more dangerous with possible complications, as the use of medication is greater and diet and eating requires greater care, and are sometimes not properly performed. In addition, the main cause of morbidity and mortality of the Brazilian population, according to the Ministry of Health, is cardiovascular disease, where two of the main risk factors are $\mathrm{SAH}$ and $\mathrm{DM}^{21}$.

Another disease mentioned by the participants was arthritis, with a notable prevalence among women, as none of the older men reported having this disease. This finding is consistent with literature, which reveals that the disease affects mainly women over 40 years of age. The female sex is more affected by arthritis than the male sex at a proportion of approximately 3:1, with some studies highlighting an even worse prognosis among women ${ }^{22}$.

As for symptoms and manifestations, hearing loss (68.57\%), musculoskeletal and osteoarticular pain $(61.43 \%)$ and persistent sadness (44.29\%) prevailed among the participants. It should be highlighted that substantiating the findings related to arthritis, the majority of women $(73.08 \%)$ again reported symptoms of musculoskeletal and osteoarticular pain. These data reflect the need for Family Health professionals to develop alternative care and therapeutic strategies, especially in the field of health promotion, with a view to preventing the worsening of the health of patients who, in addition to such comorbidities, also had a sedentary lifestyle, as shown in the physical activity component of the ILP scale.

Hearing loss was the most prevalent symptom among participants in this study. Age-related hearing loss is one of the most frequent and disabling physiological changes in the human aging process. Such a loss can trigger problems related to the social and family participation of older adults, who often show less interest in carrying out daily activities, in addition to perceiving themselves as helpless when faced with life and in relation to others ${ }^{23}$.

Such a feeling of helplessness can lead to distancing and a low demand for health services. The challenge for FHS professionals is to ensure access for this population with impaired hearing, which must be strengthened and improved in order to guarantee continuity of treatment and integral care.

The feeling of persistent sadness was also frequently reported among women (53.85\%). Confirming this fact, literature shows that the feeling of sadness associated with loneliness is often 
related to mourning, resulting from the death of a spouse, and mainly affects women, who are more often widowed. These negative feelings can worsen and determine symptoms of a depressive condition, associated with physical weakness, emotional fragility and difficulties in family and social relationships ${ }^{24}$.

Regarding falls, while the present study did not present a high prevalence of such events among the participants, it is important to highlight that the early and correct identification of the main risk factors for falls converges with the possibility of preventing such accidents and, consequently, improving the quality of life of the older adults ${ }^{17}$.

As for lifestyle, the scale used allowed this characteristic to be considered individually, so that later, intervention strategies and directive sessions could be implemented to reduce less healthy lifestyles.

The nutrition and physical activity components had the lowest scores, and were classified as negative, with men obtaining a lower score than women. In relation to physical activity, Da Silva et. al. ${ }^{25}$ statistically demonstrated that the practice of regular physical activity declines as age increases, falling to between $20.7 \%$ and $27.5 \%$ in studies conducted in Brazil.

Regarding nutrition, participants of both sexes had a positive profile classification, although men had a lower score than women. In the older population, it is also important to consider variables at personal, family and community levels. The causes and influences that lead to unhealthy food choices are complex and multidimensional, and greater investments in research, surveillance, prevention, health promotion and the support of healthy living are required ${ }^{26,27}$.

The five components analyzed by the Nahas Lifestyle Profile Scale (nutrition, physical activity, preventive behavior, social relationships and stress control) are essential for people in all age groups, as they are complementary, reveal interdependence and specificity, allowing the individual's lifestyle, way of thinking and acting to be identified, all of which have a great influence on general health and quality of life.

Although the findings of studies of this nature cannot be expanded to more general populations, the relevance for planning and decision-making by health professionals and local managers is undeniable, as they allow the planning of actions to prevent diseases and injuries based on a real context.

\section{CONCLUSION}

The realization of the present study allowed the sociodemographic and clinical characterization of older adults treated by Primary Health Care professionals, providing a situational diagnosis and an analysis of health indicators, which can be replicated in new scenarios. In terms of sociodemographic data, there was a predominance of women and the marital status of married, and the main source of income cited was pensions. With regard to clinical conditions, more than half of the participants of both sexes were overweight, the most cited comorbidities were hypertension and arthritis and the most common symptoms were sadness and hearing loss.

When constructing the situational diagnosis of older adults with diabetes, it is noticeable that this is one of the main diseases that greatly affect different aspects of the lives of these patients and reveals the complexity involved in reorienting lifestyle based on this medical diagnosis.

For this reason, the FHS must seek to help individuals with diabetes make changes in their lifestyle, by raising the population's awareness of the importance of health promotion (suitable eating habits, an active life favoring the reduction of risk behaviors on a daily basis). Furthermore, situational diagnosis enables the provision of specific and qualified care and is of great importance for the foundation of care based on interprofessional collaboration.

Edited by: Ana Carolina Lima Cavaletti 


\section{REFERÊNCIAS}

1. World Health Organization. Informe mundial sobre la diabetes: Resumen de Orientación. Genebra: WHO; 2016.

2. Sociedade Brasileira de Diabetes. Posicionamento Oficial SBD nº 01/2019. Conduta Terapêutica no Diabetes Tipo 2: Algoritmo SBD [Internet]. São Paulo: SBD; 2019 [acesso em 28 ago. 2019]. Disponível em: https://www.diabetes.org.br/publico/ images/pdf/sbd_dm2_2019_2.pdf

3. Schenker M, Costa DH. Avanços e desafios da atenção à saúde da população idosa com doenças crônicas na Atenção Primária à Saúde. Ciênc Saúde Colet [Internet]. 2019 [acesso em 28 ago. 2019];24(4):1369-80. Disponível em: https://www. scielo.br/scielo.php?script=sci_arttext\&pid=S141381232019000401369\&tlng=pt

4. Duarte ENC, Marques APO, Leal MCC. Qualidade de vida em idosos diabéticos assistidos na estratégia de saúde da família. Rev Baiana Saúde Pública. 2018 [acesso em 02 set. 2019];42(1):109-25. Disponível em: http://rbsp.sesab.ba.gov.br/index.php/rbsp/article/ view/2501/2442

5. Lanzoni GMM, Meirelles BHS, Cummings G. Práticas de liderança do enfermeiro na atenção básica à saúde: uma teoria fundamentada nos dados. Texto \& Contexto Enferm. 2016 [acesso em 25 ago. 2019];25(4):1-9. Disponível em: http://www.scielo.br/scielo.php?pid=S0104$07072016000400305 \&$ script $=$ sci_arttext\&tlng=pt

6. Programa das Nações Unidas para o Desenvolvimento. Atlas do desenvolvimento humano no Brasil [Internet]. S.1: PNUD; 2013. Disponível em: http://atlasbrasil.org.br/2013/

7. Ceará. Secretaria de Saúde, Coordenadoria de Promoção e Proteção à Saúde, Núcleo de Informação e Análise em Saúde. Caderno de Informação em Saúde: Região de Saúde Acaraú. Fortaleza: SESA; 2014.

8. Instituto Brasileiro de Geografia e Estatística. Cidades. Jijoca de Jericoacoara [Internet]. Rio de Janeiro: IBGE; [1995] [acesso em 14 jun. 2018]. Disponível em: http:// www.cidades.ibge.gov.br/xtras/perfil.php?lang=\&cod mun $=230725 \&$ search $=$ ceara $\mid$ jijoca-de-jericoacoara

9. Brasil. Ministério da Saúde. Orientações para coleta e análise de dados antropométricos em serviços de saúde: norma técnica do sistema de Vigilância Alimentar e Nutricional. Brasília, DF: Ministério da Saúde; 2011[acesso em 20 maio 2019]. (Série G. Estatística e Informação em Saúde). Disponível em: http://dab.saude.gov.br/portaldab/biblioteca. php?conteudo=publicacoes/orientacoes_coleta_ analise_dados_antropometricos
10. Nahas MV, Barros MGV, Francalacci V. O pentáculo do bem estar: base conceitual para a avaliação do estilo de vida em indivíduos ou grupos. Rev Bras Ativ Fís Saúde. 2000;2(5):48-59.

11. Both J, Borgatto AF, do Nascimento JV, Sonoo CN, Lemos CAF, Nahas MV. Validação da escala "perfil do estilo de vida individual". Rev Bras Ativ Fís Saúde. 2008;13(1):5-14.

12. Pimenta SE, Martins MM, Monteiro C, Reis SM, Martinho J. Elderly people with limited mobility: their families and the implications of their dependency. Rev ROL Enferm. 2018 [acesso em 20 jun. 2018];41(11-12):217-21. Disponível em: http:// comum.rcaap.pt/handle/10400.26/31742

13. Vitoi NC, Fogal AS, Nascimento CM, Franceschini SCC, Ribeiro AQ. Prevalência e fatores associados ao diabetes em idosos no município de Viçosa, Minas Gerais. Rev Bras Epidemiol [Internet]. 2015 [acesso em 12 set. 2019];18(4):953-65. Disponível em: https://www.scielosp.org/article/rbepid/2015. v18n4/953-965/

14. Instituto Brasileiro de Geografia e Estatística. Pesquisa Nacional de Saúde: 2013: Percepção do estado de saúde, estilos de vida e doenças crônicas [Internet]. Rio de Janeiro: IBGE; 2015 [aceso em 02 out. 2019]. Disponível em: https://biblioteca.ibge.gov. br/visualizacao/livros/liv94074.pdf

15. Roos AC, Baptista DR, de Miranda RC. Adesão ao tratamento de pacientes com Diabetes Mellitus tipo 2. DEMETRA [Internet]. 2015 [acesso em 05 ago. 2019];10(2):329-46. Disponível em: https://www.epublicacoes.uerj.br/index.php/demetra/article/ view/13990

16. Flor LS, Campos MR. Prevalência de diabetes mellitus e fatores associados na população adulta brasileira: evidências de um inquérito de base populacional. Rev Bras Epidemiol [Internet]. 2017 [acesso em 28 Set. 2019];20(01):16-29. Disponível em: https://www.scielo. br/scielo.php?script=sci_arttext\&pid=S1415-790X2017 000100016\&lng $=$ pt\&tlng $=$ pt

17. Wanderley RMM, da Cunha DGP, Felisberto MAS, de Oliveira BRS, Bittencourt GKGD, Amaral AKFJ, et al. Avaliação da condição de saúde da pessoa idosa na atenção básica. Rev Enferm UFPE. 2019;3(2):472-82.

18. Ferraz MOS, Dos Reis LA, Lima PV. Condições de saúde de idosos portadores de Diabetes mellitus e hipertensão arterial sistêmica. Rev Multidiscipl Psicol [Internet]. 2017 [acesso em 01 set. 2019];10(33):56-71. Disponível em: https://idonline.emnuvens.com.br/id/ article/view/599/856 
19. Brasil. Ministério da Saúde, Secretaria de Atenção à Saúde, Departamento de Atenção Básica. Estratégias para o cuidado da pessoa com doença crônica: diabetes mellitus. Brasília, DF: MS; 2013.

20. Burgos MGPA, dos Santos EM, Morais AACL, Santos OS, Melo NCO, Costa MBM. Consumo de macro e micronutrientes de idosos com diabetes mellitus tipo 2 atendidos no núcleo de apoio ao idoso. Med (Ribeirão Preto) [Internet]. 2019 [acesso em 30 ago. 2019];52(2):121-7. Disponível em: https:// www.revistas.usp.br/rmrp/article/view/159721

21. Brasil. Ministério da Saúde, Secretaria de Atenção à Saúde, Departamento de Atenção Básica. Estratégias para o cuidado da pessoa com doença crônica: diabetes mellitus. Brasília, DF: Ministério da Saúde; 2013.

22. Pereira MS, Luz DCM, Ramos JMN, Khouri PBS, Viana Neto RE, Souza CMF, et al. Avaliação do perfil sociodemográfico, clínico, laboratorial e terapêutico dos pacientes com artrite reumatoide em um ambulatório-escola de Teresina, Piauí. Arch Health Invest. 2017;6(3):125-8.

23. Camargo C, Lacerda ABM, Sampaio J, Lüders D, Massi G, Marques JM. Percepção de idosos sobre a restrição da participação relacionada à perda auditiva.
Distúrb Comun [Internet]. 2018 [acesso em 02 out. 2019];30(4):736-47. Disponível em https://revistas. pucsp.br/dic/article/viewFile/35364/27293

24. Meneses DLP, da Silva Júnior FJG, Melo HDSF, Carvalho J, de Sousa Luz VLE, Figueiredo MDLF. A dupla face da velhice: o olhar de idosos sobre o processo de envelhecimento. Enferm Foco [Internet] 2013 [acesso em 02 out. 2019];4(1):15-8. Disponível em http://revista.cofen.gov.br/index.php/ enfermagem/article/view/495

25. Da Silva E, de Souza AC, Kumpel C, Souza JS, Porto EF. Estilo de vida de indivíduos usuário do sistema único de saúde. Life Style [Internet]. 2018 [acesso em 03 out. 2019];5(2):61-5. Disponível em: https://revistas. unasp.edu.br/LifestyleJournal/article/view/1073

26. Brasil. Ministério da Saúde. Relatório do $3^{\circ}$ Fórum de monitoramento do plano de ações estratégicas para o enfrentamento das doenças crônicas não transmissíveis no Brasil. Brasília, DF:MS; 2018.

27. Organização das Nações Unidas. FAO alerta para obesidade na América Latina e Caribe [Internet]. [S.1]: ONU; 2018 [acesso em 07 mar 2018]. Disponível em: http://bit.ly/35I8WAQ 